\title{
HEALTH INSURANCE STATUS AND PERCEIVED QUALITY OF HEALTH SERVICE AT COMMUNITY HEALTH CENTER, SUMENEP, EAST JAVA
}

\author{
Khoirotun Nisa Uswatun Khasanah'), Bhisma Murti²), \\ Ari N Probandari3) \\ 1)Masters Program in Family Medicine, Universitas Sebelas Maret \\ 2)Masters Program in Public Health, Universitas Sebelas Maret \\ 3)Faculty of Medicine, Universitas Sebelas Maret
}

\begin{abstract}
Background: Having health insurance is important for several reasons. As studies have shown, uninsured people receive less medical care and less timely care. They have worse health outcomes, and lack of insurance is a fiscal burden for them and their families. This study aimed to assess the relationship between health insurance status and perceived quality of health service at community health center, Sumenep, East Java.

Subjects and Method: This was a cross-sectional study conducted at puskesmas (community health centers) in Sumenep, East Java. A total sample of 250 people who visited the puskesmas in Sumenep were selected for this study. The dependent variable was perceived quality of health services. The independent variables were health insurance status, sex, age, education, and job. The data were collected by questionnaire and analyzed by a multiple linear regression.

Results: Member of health insurance $(b=6.21$; CI 95\% $=-2.75$ to $-9.68 ; p<0.001)$ and female $(b=1.35$; CI 95\% $=-1.35$ to $-3.23 ; \mathrm{p}<0.001)$ were associated with better perceived quality of health service. Age ( $b=0.50$; CI $95 \%=-2.24$ to $3.25 ; p=0.72)$, higher education $(\mathrm{b}=-0.94 ; \mathrm{CI} 95 \%=-0.21$ to $3.89 ; \mathrm{p}=0.53)$, and having a job $(\mathrm{b}=$ 0.94 ; CI $95 \%=-2.01$ to $3.89 ; \mathrm{p}=0.52$ ) were associated with poorer perceived quality of health services.

Conclusion: Member of health insurance and female are associated with better perceived quality of health service. Age, higher education, and having a job are associated with poorer perceived quality of health services.
\end{abstract}

Keywords: perceived quality of health service, national health insurance

\section{Correspondence:}

Khoirotun Nisa Uswatun Khasanah. Masters Program in Family Medicine, Universitas Sebelas Maret, Jl. Ir. Sutami 36A, Surakarta 57126, Central Java. Email: aihachimitsu@gmail.com. Mobile: 081939476779 